\title{
Ecotourism community enterprises and ethnodevelopment: modelling the Kalunga empowerment possibilities in the Brazilian savannah
}

\author{
Ismar Borges de Lima ${ }^{1,2^{*}}$, Peter A. Kumble ${ }^{3}$, Maria Geralda de Almeida ${ }^{4}$, Eguimar Felício Chaveiro ${ }^{4}$, \\ Lara Cristine Gomes Ferreira ${ }^{4}$ and Rosiane Dias Mota ${ }^{4}$
}

\author{
*Correspondence: \\ ismarlima@yahoo.com.br \\ ${ }^{2}$ MultiAmazon/State \\ University of Roraima, UERR, \\ and RECINATUR, Rua Sete de \\ Setembro, 291, Canarinho, \\ Boa Vista CEP 69303-530, \\ Roraima, Brazil \\ Full list of author information \\ is available at the end of the \\ article
}

\begin{abstract}
This paper investigates the Kalunga community demands for income generation through ecotourism enterprises in the north of Goias State, in the Brazilian savannah. As part of the analysis, the paper discusses the main aspects of the community empowerment framework. It identifies the existing natural and cultural assets of the Kalunga and the community need for capacity building aimed at dealing with a growing tourism business and managing visitors. This afro-descendant community expects ecotourism to serve as a development as a catalyst for economic development by propitiating financial independence through ecotourism community enterprises. These issues require the elaboration of an ethnic operational business model for the community, which is one of the main contributions of this paper. There is insufficient literature on the Kalunga maroon community, particularly related to ethnic-based business and enterprises. This paper investigating the Kalunga is important because it can reveal 'the silences' and the 'innermost facts' of a slow, but evolving process of social and economic emancipation of this African-descendant group, one that in the past (date) highly segregated itself from enslavement. This paper also makes an original contribution to research knowledge by comprehensively examining the possibilities for community empowerment from the within as an ethnodevelopment process. The main issues lie in the fact that the Kalunga cannot continue to be perceived by outsiders as 'cheap labour' on their own lands; they must take ownership of their own assets, means for survival and long-term fate. The research is predominantly qualitative based on field research, participant observation, interviews with key informants, and written survey with a focus group.
\end{abstract}

Keywords: Ecotourism, Community enterprises, Community ethnodevelopment, Income generation, Community empowerment, Financial and social emancipation, Kalunga, Brazil

\section{Background}

Nature-based tourism within the high-mountain Kalunga communities corroborates what other acknowledged studies and research have revealed: there is great economic,

\section{Springer}

(C) 2016 de Lima et al. This article is distributed under the terms of the Creative Commons Attribution 4.0 International License (http://creativecommons.org/licenses/by/4.0/), which permits unrestricted use, distribution, and reproduction in any medium, provided you give appropriate credit to the original author(s) and the source, provide a link to the Creative Commons license, and indicate if changes were made. 
social and environmental values of tourism to be found with some isolated and culturally distinctive communities, (Lindberg and Hawkins 1998; Buckley et al. 2003; Singh et al. 2003; Lima 2011, 2014a, b; Lima and Weiler 2015; Lima and Kumble 2015; Almeida 2010, 2014, 2015; Ramos and Almeida 2014). Of equal importance it is the role of tourism for capacity building, or the opening up of opportunities for members of local communities in order to learn and develop specific skills such as tour guides (Brasileiro and Pena 2015; Lima and Kumble 2015). Community capacity building is understood as a process which can strengthen the capacity of individuals and of organisations to the extent they are able to support various aspects of a community life and development (Blackwell and Colmenar 2000; Aref and Redzuan 2009).

It was learned from interviews and a survey that the Kalunga have high demands for increased institutional support and development of on-site tourism structures and facilities, including a visitor hostel. This can be interpreted as a means for building or reinforcing local assets that can foster 'social economy' (Molloy et al. 1999; Bennett et al. 2010; Johnson 2010) based on 'community learning' (Falk and Harrison 1998; Kilpatrick 2000) with a focus on entrepreneurial spirit, social enterprises, and integrated planning for community empowerment (Sofield 2003; Beeton 2006). Community Learning is often misrepresented to refer to 'learning individuals' within a certain community (Falk and Harrison 1998), but Marinho (2013) understand it as a 'group (community) learning "when all members perceive themselves as having contributed to a group outcome, and all members of the group can individually describe what the group as a system knows" (p. 250), as expressed in attitudes that demonstrate a collective capacity to produce results which matter for them (the community, the group) (Topolsky 1997). Community is defined as a group of individuals belonging to a particular geographic location with similar interests, identity, values, and social practices (Beeton 2006). Some authors consider 'community' as a 'learning organisation' in rural development (Schianetz et al. 2007; Moore and Brooks 1996).

Survey work by the authors found the demand or need for increased 'ethnic entrepreneurship', a phenomena supported in the literature (Yang and Wall 2008; Miral et al. 2013). Respondents often cited the need for the following infrastructure development: to build hostels and, or, traditional-styled cottages; or, to assist some of the families so they can provide overnight homestays in their traditional houses. This would allow the visitor to experience an immersion in local family routines, rather than over-nighting in the city hotels. Other goals included improvement and creation of camping sites; and to improve the Kalunga restaurants and food services. Some respondents also added that 'loans concession' by the government or others would be of great advantage, so they could improve tourism infrastructure while also creating new ethnically-related tourism products for sale. As for this article, 'ethnic entrepreneurship' is interchangeably used to refer to 'Kalunga entrepreneurship', 'maroon' or 'quilombola entrepreneurship'. The term 'maroon' refers to a community member or members of a community who were originally descended from escaped slaves in the 18th and 19th Centuries; a group of people of dark brownish-red color living in remote places which are difficult to be reached. Weik (1997, p. 81) refers to maroons as "peoples of the African Diaspora who escaped from enslavement and lived independently of plantation societies in the Americas" (as cited by Hart 1985), and in the Brazilian historiography, a Maroon community is 
called a quilombo [or quilombola], a magote, or a mocambo (Schwartz 1979). If and well planned, ethno-cultural tourism results in a much more meaningful experience for people and nature. More importantly, it is enabling the Kalunga to become skilled and confident enough for autonomously making decisions and implementing actions for land management, including tourism planning and management, and accountability (Lima and Kumble 2015; Brasileiro and Pena 2015; Amorim 2015). Actions towards a Kalunga nature-tourism entrepreneurial model may symbolically represent a milestone between centuries of oppression faced by generations made slaves and promising decades for a new generation formed by skilled free-to-decide entrepreneurial people through "participative planning and decision-making [...] providing transparency in planning issues counteracts the often observed initial resistance to change and any defensiveness against decisions" (Schianetz et al. 2007, p. 1490).

A community institutionalised and modestly equipped tourism venture operated by the Kalunga has been shown to achieve group-managed sturdy income source and longlasting financial autonomy (emancipation), as observed at other maroon and indigenous communities around the world. For example, the Whale Watch Kaikoura is a non-profit Maori community business (Lima and Weiler 2015), with $48 \%$ owned by Ngai Tahi and $52 \%$ by local 'hapu'-a local iwi and subtribe respectively. This business generates income for local marae (a communal tribal community) in New Zealand (Orams 2002). Another example of success is the indigenous community of Peguche Reserve located in Imbabura, Ecuador (Tapia and Trujillo 2014).

Table 1 contains a list of successful Quilombola entrepreneurship initiatives in Brazil. This article discusses the main legal and policy issues related to the Kalunga quilombola site. The investigation is mostly qualitatively oriented; percentage-based analysis is done for statistically understanding the Kalunga views. A conceptual discussion is also offered supporting the theme of 'ethnic issues', 'ethnicity', 'social justice' (Trimble and Fisher 2006), and 'ethnodevelopment' (Lima 2014a, b; Willis 2005). Based on findings and outcomes of the research, three interrelated diagrams are proposed for systematically understanding and structuring the operational lines of 'ethnic-based tourism entrepreneurship' (Miral et al. 2013).

As discussed earlier, published empirical research about the Kalunga maroon community is still scarce, particularly international publications in English related to ethnic business and enterprises. However, study of the Kalunga is important because it can reveal the silences and the innermost facts of a slow, but evolving process of social and economic emancipation of an African-descendant group of highly segregated slaves. Given this point of view, what are the possibilities for Kalunga community empowerment through ecotourism practices? The aim is to demonstrate a course of action, to emancipate the Kalunga community through financial pooling and training in self-confidence as entrepreneurs. The main accounts lie in the fact that the Kalunga cannot be continually perceived as a 'cheap labour' on their own land; rather, they must take ownership of their own assets, means for survival, and future.

\section{The Kalunga, a maroon Quilombola in Brazil}

The Brazilian Quilombo communities, among them the Kalunga, were officially recognised by the Brazilian government with the publication of Article 68 of the 1988 
Table 1 Some examples of existing Quilombola entrepreneurships in Brazil

\begin{tabular}{|c|c|c|c|c|}
\hline \multicolumn{2}{|c|}{ Product(s) } & \multirow{2}{*}{$\begin{array}{l}\begin{array}{l}\text { Scope/arrangement } \\
\text { type }\end{array} \\
\begin{array}{l}\text { Non-timber product } \\
\text { extraction cooperative } \\
\text { (standing forest } \\
\text { business) }\end{array}\end{array}$} & \multirow{2}{*}{$\begin{array}{l}\text { Quilombo name } \\
\begin{array}{l}\text { Various Quilombo inte- } \\
\text { grate the cooperative. }\end{array}\end{array}$} & \multirow{2}{*}{$\begin{array}{l}\text { Location } \\
\text { Oriximina, Amazon region }\end{array}$} \\
\hline 1 & $\begin{array}{l}\text { Brazil nut } \\
\text { Copaiba oil }\end{array}$ & & & \\
\hline 2 & Mud handicrafts & Cooperative/association & $\begin{array}{l}\text { Sitio Muquem, Uniao dos } \\
\text { Palmares }\end{array}$ & $\begin{array}{l}\text { Zona da Mata, Alagoas } \\
\text { State }\end{array}$ \\
\hline 3 & $\begin{array}{l}\text { Label rouge Chichen } \\
\text { breeding and meat } \\
\text { production }\end{array}$ & Family/group/community & Veloso & Pitangi, Minas Gerais State. \\
\hline 4 & Bakery & Association & Sitio dos Grossos & $\begin{array}{l}\text { Bom Jesus, Rio Grande do } \\
\text { Norte }\end{array}$ \\
\hline 5 & $\begin{array}{l}\text { Ethnic tourism } \\
\text { Dende Oil } \\
\text { Oyster production } \\
\text { Handicrafts }\end{array}$ & Community & Kaonge & $\begin{array}{l}\text { Santiago do lguape, } \\
\text { Cachoeira, Reconcavo, } \\
\text { Bahia State. }\end{array}$ \\
\hline 6 & $\begin{array}{l}\text { Biriba seedling and } \\
\text { reforestation } \\
\text { Cabaças (gourd) } \\
\text { cultivation }\end{array}$ & Community & Cordoaria & Camacari, Bahia State. \\
\hline 7 & $\begin{array}{l}\text { Community-based } \\
\text { tourism }\end{array}$ & Multiple communities & $\begin{array}{l}\text { Pedro Cubas } \\
\text { Andre Lopes } \\
\text { Nhunguara } \\
\text { Sapatu } \\
\text { Ivaporunduva } \\
\text { Sao Pedro }\end{array}$ & $\begin{array}{l}\text { Eldorado and Iporanga, in } \\
\text { the Vale do Ribeira, Sao } \\
\text { Paulo State }\end{array}$ \\
\hline
\end{tabular}

Source: various online. Accessed 20.04.2015

National Constitution. Article 68 offers certain guarantees: Land ownership rights, territory demarcation, and general recognition. It also addresses more general but not less relevant issues, such as socioeconomic, spatial, cultural, and jurisdictional issues (Pare et al. 2007). The insertion of Quilombo communities into the Constitution served to deal with historical and emblematic issues of the representativeness of the afro-ethnical groups in Brazilian society (Franco and Tarrega 2015; Amorim 2015). Patently, it was the first recognizable action of the government towards the reparation of a historical injustice against a group of people who were profoundly oppressed for generations and are still facing ethnic and racial constraints in land ownership and resource management (Amorim 2015; Franco and Tarrega 2015; Almeida 2014; Marinho 2014; Lima and Kumble 2015), despite increased public awareness and various advances in the social area.

The Kalunga lands, properly named "Historical and Cultural Heritage Kalunga Site" (Territory/Land), belong to a macro ecological area called Biosfera Goyaz Reserve (Lima and Kumble 2015, p. 194). The site has nearly 6000 inhabitants who occupy an area of 237,000 hectares (FGV-Fundação Getúlio Vargas 2010). The Kalunga site is situated close to National Park Chapada dos Veadeiros, whose total area is 2,137,700 hectares. The Chapada is a fully protected ecological reserve, and residents of Kalunga are not allowed within its limits. It is surrounded by an Area of Environmental Protection (APA), called Pouso Alto, which allows human presence and anthropic interventions to occupy up to $30 \%$ of the land, either for farming, industry, deforestation, or corporate ranching, if legally authorised by Ibama and in accordance with the district natural resource management plan (Almeida 2015; Lima and Kumble 2015; Franco and Tarrega 2015). 
The region of Chapada National Park comprises six counties, including Cavalcante, Teresina and Monte Alegre, which are municipalities where most Kalunga communities are located. Portions of the Kalunga lands are within the APA and as such are subjected to restricted anthropic use. The Avá-Canoeiros Indigenous territory is a neighboring area, in the north eastern-most part of Colinas do Sul County; it has 19,148 hectares for just six Avá-Canoeiro individuals; this indigenous population has been reducing dramatically over the decades and it is at high risk of extinction (Begnini 2003). To summarize, there is a mosaic of land partitions with varied protection statuses and complex tenure issues to be taken into account with any research performed in order to fully understand the context and history of the Kalunga groups. Also, the Kalunga groups are not the only ethnic group living in the region. Brito Neto (1995) advocates that Kalunga, or, Calunga, are not a typical Brazilian quilombo; rather, contrary to mainstream research, he assures that Kalunga are humble peasants struggling for survival and seeking for their rights as citizens.

The Kalunga have struggled to strengthen their culture and to become self-financing and economically independent. Therefore, any ethno-development-based on the premises of a participatory grassroots decision-making process to administer internal issues-should take place (Lima 2014a, b; Lima and Kumble 2015; Faria 2005; Silva and Carvalho 2010). For Stavenhagen (1985), the term "ethno-development" has two major approaches in literature, either being explained as "the economic development of a group ethnic" or being described as "the development of the ethnicity of a social group". Little (2002) advocates that these two meanings are not self-exclusive; and they have dialectical bonds because "development of ethnicity" without "corresponding economic advances" can only produce a marginal ethnic group (p. 39-40).

Thus, economic advances of an ethnic group are intrinsic conditions of ethno development. And, an ethno-cultural and ecological tourism seems to serve as one of the pillars in the cultural-economic nexus for ethno-development. For Brito-Neto (1995, 2005), everything that is produced by an individual-material or immaterial assets-is part of their cultural heritage, and "ethnic elements" do belong to this heritage scope the same way. As underlined by McKercher and Cros (2002), the... [Immaterial] "cultural or heritage assets may serve a multitude of user groups, including tourists...but also 'traditional owners' such as indigenous or ethnic community groups that own the intellectual cultural property or land rights" (p.7).

As one talks about linking "heritage", "ethnicity" and "culture" to tourism, a definition of "cultural tourism" and "ethno-tourism" is binding, because "the universe of culture has been historically created, and the meanings, values and views which constitute it must be explained' (Meneses 2002, p. 92). Ethno-tourism is a type of "cultural tourism" whose appeal can be found in the identity and the culture of a particular ethnic group. And, ethnic tourism and indigenous tourism can be one of the types of ethno-tourism (Faria 2005, p. 73).

As for "cultural tourism", it is succinctly and clearly defined by the UNWTO as, "the movement of persons to cultural attractions in cities in countries other than their normal place of residence, with the intention to gather new information and experiences to satisfy their cultural needs" (2005). In this way the role of culture is contextual and is related to a visitor's general cultural experience without a particular focus on the 
uniqueness of a specific cultural identity (Wood 1984). This is generally true as one observes visitors who choose to go to the Kalunga territory; they not only focus on one single aspect of the Kalunga culture, but they go there expecting a broad afro-Brazilian experience, nature enjoyment and contemplation, and self-satisfaction (Almeida 2014). "Territory" is used in this paper to refer to an area in a county, or within counties, where the Kalunga groups are situated; "Territory" does not denote an official autonomous jurisdictional district. As such, the Kalunga territory does not consist of geo-political boundaries. In the Kalunga territory not only is cultural tourism or ethno-tourism now in demand, but also nature-based tourism and ecotourism prevail with an increasing number of outsiders making visits to Engenho 2 because of the natural attractions and preserved landscape (Almeida 2014; Ramos and Almeida 2014).

\section{Ecotourism Kalunga as a local entrepreneurship initiative: understanding the context, community and the natural assets}

Currently, the Kalunga communities in the northeast of Goias are part of the Historic and Heritage Kalunga Site, created by the Supplementary Law of Goias, number 19, of the 5th of January, 1996 (Franco and Tarrega 2015; Lima and Kumble 2015). Their territory stretches over an area of 237,000 hectares in the region (FGV-Fundação Getúlio Vargas 2010). As proposed by Marinho (2008), these communities were divided into four main centers: "Engenho 2", Vao do Moleque, Vão de Almas, and Ribeirao dos Negros, later renamed as Ribeiro dos Bois. Kalunga is a maroon group and they are mostly clustered in rural settlements called 'quilombolo' or 'quilombola' in Brazil (Brasileiro and Pena 2015; Marinho 2014; Almeida 2014, 2015; Ramos and Almeida 2014; Lima 2014a, b; Lima and Kumble 2015).

Cavalcante County itself hosts the largest Quilombo of Brazil with nearly 6000 dwellers. Cavalcante County has 154 waterfalls catalogued, some of which can be reached by the visitors alone, but most of them requiring a local guide, as is the case with the Kalunga. With tourism booming in Cavalcante, the city has experienced an increase in the number of hostels, restaurants and tour operators (Ungarelli 2009), and consequently there has been an increase in the number of visitors interested in visiting the Kalunga lands to experience their culture and visit the waterfalls, but the consolidation of "tourism in the land of black people" has been an crusade with various challenges (Brasileiro and Pena 2015).

Of these Kalunga communities, Engenho 2, has been better equipped in terms of infrastructure and local human resources for dealing with tourism, visitors and their demands. Engenho 2 is also the closest community to more densely developed communities of Cavalcante and Alto Paraíso, making it the easiest one to be accessed by the visitors, tour agencies, and operators. It is relevant to note that there is no territorial boundary between the Kalunga communities (Brasileiro and Pena 2015; Lima 2014a, b; Lima and Kumble 2015; Marinho 2014). In fact, the divisions, limits and inner-territorial separation are marked by certain natural elements: the various mountain ridges, streams and rivers with their iconic waterfalls. According to Almeida (2009), the existence of the Kalunga territory has been an important factor for environmental preservation and landscape conservation. The region has a great scenic appeal and a natural heritage with 
unique falls, caves, streams, rivers, lakes, exotic rock formations, hills, and a rich fauna and flora with thousands of endemic species (Ramos and Almeida 2014).

Tourism is just one more activity for income generation for the Kalunga families, and together with the cultivation of subsistence crops, vegetable gardens, orchards, fishing, natural product extraction, breeding of cattle, pigs, and of birds secures their livelihood (Velloso Velloso 2007; Baiocchi 1999; Ungarelli Ungarelli 2009). But, in Engenho 2 the Kalunga people have lost part of their land to farmers, and this has been an issue for territorial disputes and tenure conflicts dating back to the 1980's because of land scams and because the farmers have a capitalist view towards the land (Velloso Velloso 2007; Ungarelli 2009, p. 26) which largely contrasts with the Kalunga's view and perceptions of that land.

As of 2014, there were approximately 85 families in Engenho 2; approximately 20 of which were directly involved in ecotourism activities, acting mostly as guides. However, the entire Kalunga area accounts for nearly 85 families engaged in tourism-related activities. To better accommodate ecotourists, Engenho 2 are in a process of capacity building with courses and training such as environmental interpretation of the trails and the waterfall areas, first aid, and interpersonal communication skills, development and hospitality (Almeida 2014, 2015; Ramos and Almeida 2014). The capacity building has been the work of NGOs, educational and professional institutions, tour operators Centro de Excelencia de Turismo da Universidade de Brasilia, Travessia Ecoturismo, SESI/SESC (mixed public-private-civil institutions with a social role for the workers), and the district government departments and agencies. According to Isabel, president of the Kalunga Guides Association, she advocates that tourism must be all-encompassing reaching other areas of the Kalunga lands in a way that can more democratically benefit the families. Another issue she raised is that the Kalunga leaders want a more intense mix of ethno-cultural tourism with ecotourism.

Capivara-I waterfall is the closest natural attraction to the Kalunga Land main gate, at about $800 \mathrm{~m}$ distance, but the trail may require more preparation for physically challenged visitors because of steep rocky walls. On the trail, visitors may choose to swim and enjoy the ponds, streams and landscape rather than pushing their physical limits to get to Capivara I. Visitors are not allowed hiking the trails by themselves and must pay a $\mathrm{R} \$ 5$ (US\$ 3.12) community fee to gain access. Additionally, they need to pay the guide(s) directly; the guides usually charge between R $\$ 5$ and R $\$ 10$ (US\$ 3.12-US\$ 6.25) per visitor, and the groups are of up to ten people. Large groups are divided among the guides for safety reasons, group control and in order to manage any possible environmental impact, such as rubbish, leftovers, and visitors who may insist on diverting from the trails to enter the woods. As one can note, the guiding fee is indeed very little money paid even if summed up with regards to ten visitors. Some guides reported not having large groups or very sporadic visitors, mostly every other weekend. This is because of low visitation or because the guider-working-roster with predetermined schedules.

According to a 2010-report of the Fundação Getúlio Vargas (FGV), some projects must address the cultural tourism infrastructural needs in Cavalcante such as the Installation of the Program Kalunga Village (FGV report) for an orderly territorial visiting in Engenho 2. The report also cites the need to create the Museum of the Quilombola Culture in Cavalcante. As for ecotourism activities, the FGV report underlines the 
importance of paving the strategic highways such as GO-239 and repaving sections of GO-118.

In addition, a lack of adequate tourism signs and orientation is noted, as well as the need for rubbish collection and management, recycling initiatives, and installation or improvement of fresh water distribution, and sewage systems construction. The actions are a necessary complement to a high quality tourism development, being responsive to sustainability principles in the extent that they bring higher levels of comfort to the visitors and better quality of life to the locals, thus with a social concern. Tourism development cannot be focused only on the well-being and facility for the visitor, neither can it be solely focused on economic profits for the trade; rather it must be planned to produce social and environmental collective advantages (Sirico 2008; Almeida 2009; Marinho 2013; Lima 2014a).

\section{Public policies and tourism at a national and regional level regarding the Kalunga}

With a mission to improve the quality of life and for capacity building of the population in the Quilombo in Brazil, the central government has designed public policies, programs and plans with social, economic, health and infrastructure targets. One of these actions is the ongoing "Program Brazil Quilombola" (PBQ), with five major sub-programs (action plans), which aims to improve the living conditions in 743 communities (Seppir 2008; Ministry of Culture 2010). The PBQ involves 23 Ministries and agencies in order to guarantee access to land, health and education, as well as to implement housing construction, electrification, and environmental recovery; it seeks to promote local development and to propitiate a full assistance to families by welfare government programs such as Bolsa Familia.

Although the government programs mostly result in collective advantages and in wide-ranging social benefits, the welfare policies-because of their length and social extension-have been criticised by some afro-descendent leaders and Quilombo experts; they allege that the "quilombo" has become an arena for political actions over the years, rather than promoting their social and economic emancipation. Such policies and their related programs and projects have created levels of dependency to the extent that they may have effects contrary to those expected, because such policies interfere with the productive labour force. For Americo (2010), there is an inter-dependent relationship of welfare programs sponsored by the government, NGOs projects and even universities research projects.

For many, dependency connotes a type of 'welfare slavery'. It is clear that Quilombo dwellers and unprivileged afro-descendants-such as the Kalunga-want external support, but they also want to be part of 'a structured citizenship', a right that was denied to their enslaved ancestors. It is all about allowing local people to take ownership of their own issues and engaging in the whole decision-making process with legitimacy and democratic management on a participatory basis. Brito-Neto $(1995,2002)$ highlights that the Kalunga has not yet reached its universal dimension [as an ethnically relevant group] because of a lack of democratic controls [or tools....avenues] with high degree of state interference [with regulation], overprotection because of excessive welfare benefits.

It is important to underline that public policies targeting tourism development can be designed by different government spheres: district, regional, state, national and 
international (Lima 2014a). This way, tourism planning and interventions implemented by distinct public agencies may result in contrasting achievements and levels of efficiency. In Brazil, the national tourism policies became more noticeable after the 1990s as they encompassed major programs which aimed at promoting regional development and at improving the quality of life of the peripheral population by getting it engaged mainly in two kinds of tourism: Rural tourism and ecotourism. The main objectives are to increase income levels of economically unprivileged families, to improve local structure and infrastructure, and to provide the means for a broad capacity building and territorial integration.

With regards to public policies and tourism, the Brazilian government at district, state and national levels has taken some initiatives to establish a number of conditions such as institutional frameworks and structure, resource allocation, strategies and guidelines to have sustainable tourism activities as an avenue for regional development. Some of the most noticeable tourism policies in Brazil to mention are as follows, but not limited to them: National Ecotourism Program (Proecotur) launched in 1995, Vocational Training Program in Tourism, Initiation Program for Tourism in the School, Sport Fishing Program, Brazilian Handicraft Program, Program of Municipalisation of Tourism (PNMT) and Brazilian Rural Tourism Program (Silva and Campanhola 1999), and the creation of the Program for Tourism Development of the Northeast Region (Prodetur/NE) in 1992 (Beni 2006).

More recently, the Pronaf for Rural Tourism was created to support projects on family farms. These projects include colonial cafes, country hotels, typical country restaurants, and rural establishments that offer commercial sportive fishing, among others. Rural tourism and ecotourism in the Kalunga land are two activities that can largely benefit from Pronaf Rural Tourism. This program offers tools such as investment credits, training, technical assistance and rural extension. Another measure taken was the creation of a network for family rural tourism, entitled Rural Tourism in Family Farming - TRAF Tourism Network, a national coordination group involving more than 100 institutions, which gets support from the Inter-American Institute for Cooperation in Agriculture and from the Ministry of Agriculture.

All of these policies, programs, and actions designed to develop the ethno-cultural and ecological tourism activities in the Kalunga Lands bring with them an implied element that goes beyond the notions of life improvement, environmental conservation, and maintenance of lifestyles and traditions. Training and capacity building are long lasting assets because they are investments in the capacity of the individual, or of groups of individuals, to become skilled enough as human resources, which per se is the means for them to achieve an economic independence. Skilled human stocks are the result of systematic investments, specialization, politicization, and of knowledge transfer in key areas and themes. Community sustained development must be reasoned in terms of "human capital" formation (Sirico 2008; Marinho 2013).

\section{Profiling the views and perceptions of the Kalunga community about themselves, tourism and their homeland}

In order to have an understanding of the views of the Kalunga in the context of the tourism practiced by them, interviews and informal talks with key community people and 
local authorities and pertinent stakeholders were done as well as the application of ecosocial questionnaires to 20 respondents who are those people directly involved in and affected by tourism activities in Engenho 2. Three major field investigations were done between (month) 2010 and (month) 2011. The first two visits were primarily for becoming familiar with the region and the community itself. A series of informal talks were conducted which were later followed by interviews with the leaders and village dwellers. In mid-2014, four key interviews and updates were done by phoning or through the internet. Apart from that, a series of discussions with key researchers on Kalunga were performed; some of their writings and updated research were consulted.

The intention of the questionnaire was to verify the Kalunga's views and demands in regard to their financial situation, as well as to better understand the mainstream ideas and opinions for a community-based tourism entrepreneurship. The Kalunga people were very cooperative and showed themselves to be very receptive of the questionnaire and the types of questions asked. All of the survey respondents have worked as local tourism guides or are somehow linked to tourism activities. This research did not survey the entire community, but focused specifically on the views and perceptions of active or experienced residents on their experience with hosting tourism. As part of the sampling, one must consider five key interviews and 30 informal discussions with local residents. The sampling is representative for the purposes of this investigation.

The interviewees and questionnaire respondents were identified and invited to participate in the research by using a method known as 'snowball sampling. This is a technique used to find related-subjects (Given 2008) or related-individuals to a subject, theme, or to a certain context. One survey participant provides the researcher the name of another individual, who in turn provides the name of a third, hence the terminology, "a rolling snow ball" (Fink 2003; Vogt 2005), thus finding respondents and initiating a 'chain referral' (Atkinson and Flint 2001). The initial criteria for selecting the interviews focused on individuals with significant medium or long-term contact and understand of the Kalunga community, their context, group dynamics, and more importantly those people who have significant contact with the Kalunga ecotourism activities. These criteria lead to the selection of individuals who became key participants in focus group interviews. Three of those were local inhabitants, including the Kalunga Association president and the main leader of those maroon groups; two individuals outside the community participated in the interviews, the main manager of the Cavalcante County Information Centre, and a 15 year guide working in the region and close to the Kalunga.

As a methodology, this is qualitative research based on semi-structured interviews and surveys with a mix of multiple choice and open-ended questions. Results suggest that this approach usually generates plenty of abundantly detailed data that can be highly contextual and subjective, but, yet richly informative (Taylor et al. 2008). This was consistent in our work on the Kalunga as the data analysis included the identification of categories for 'common issues' and 'collective aspirations' among the Kalunga directly contributing with the research. Data reduction facilitated the process (Taylor et al. Taylor et al. 2008) for selectively identifying the 'issues of common concerns and wishes'. Thematic analysis (Guest et al. 2011) was used, and the standardization of most questions both in the semi-structured interviews and survey open questions contributed to the data reliability without compromising the way the participants freely expressed 
themselves. The data analysis was done by contrasting the main points identified in the questionnaires with the information provided by the key informants in the interviews and in the informal talks. This subjective and descriptive aspect of the research was crisscrossed with the statistical information obtained in the survey and questionnaire. The combination of both qualitative and quantitative approaches helped to find the key issues and variables for modelling a Kalunga community-based ecotourism enterprise.

The outcomes with the questionnaires on tourism in the Kalunga lands as viewed and perceived by them, $75 \%$ of the respondents stated that they do have a feeling of ownership over the tourism activities, $20 \%$ mentioned they don `t have such a feeling over the decision-making processes, and $5 \%$ of the respondents did not answer the question. As asked about whether the life of his/her family improved with tourism in the community, $75 \%$ answered 'yes', and $5 \%$ said 'no', $10 \%$ were uncertain whether it improved or not, and $10 \%$ let it in blank. Notwithstanding, it must be taken into account that the questionnaires were mostly answered by those who are directly active in the tourism in the community with at least one family member being a 'tour guide.' Another question was about whether the 'whole community' gets benefits from tourism, $65 \%$ assured that 'yes', and $35 \%$ replied 'no.' This type of question may differ from a survey with other Kalunga not working in tourism. Though, the respondents are involved with tourism, $35 \%$ acknowledge that the 'whole community' does not benefit.

Figure 1 clearly shows that the monthly salary range in the Kalunga community is quite low: 80 \% receive a minimum Brazilian salary of approximately \$341 USD, (US\$ $1=$ BRL\$ 1.80), and with $15 \%$ of the Kalunga families receiving $50 \%$ lower than the minimum salary. These percentages provide evidence of extreme poverty. Figure 2 shows that tourism guiding fees and related income generation has little impact on the monthly salary of a worker, as $65 \%$ of the respondents state that tourism contributes to only $30 \%$ of their total monthly. Only $5 \%$ believed that it contributed up to $60 \%$ for their income. Figure 3 illustrates that the major income sources are 'farming' with vegetable sales and the government welfare programs, such as 'Bolsa Familia' (Family Pension), and other occupational activities practiced by the Kalunga not related to tourism (Fig. 4).

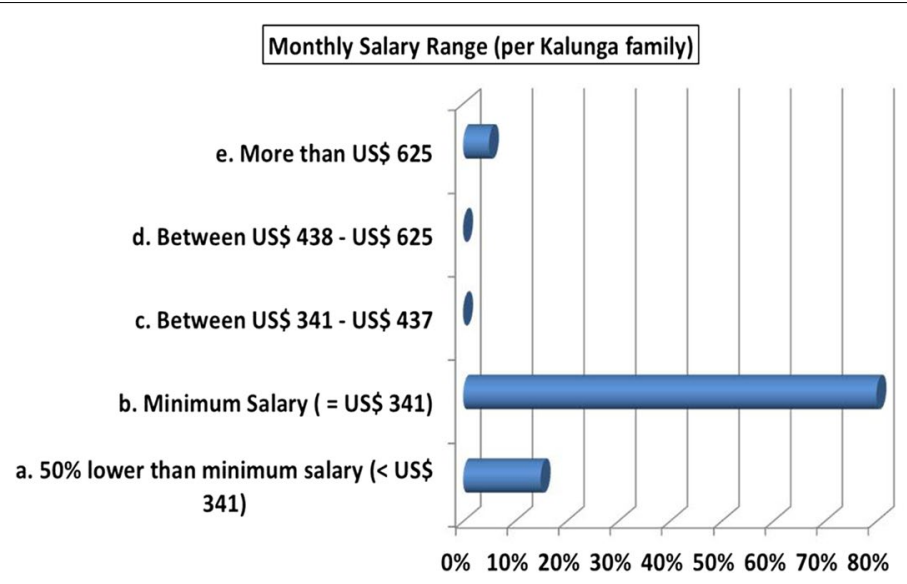

Fig. 1 Kalunga monthly salary range per family 

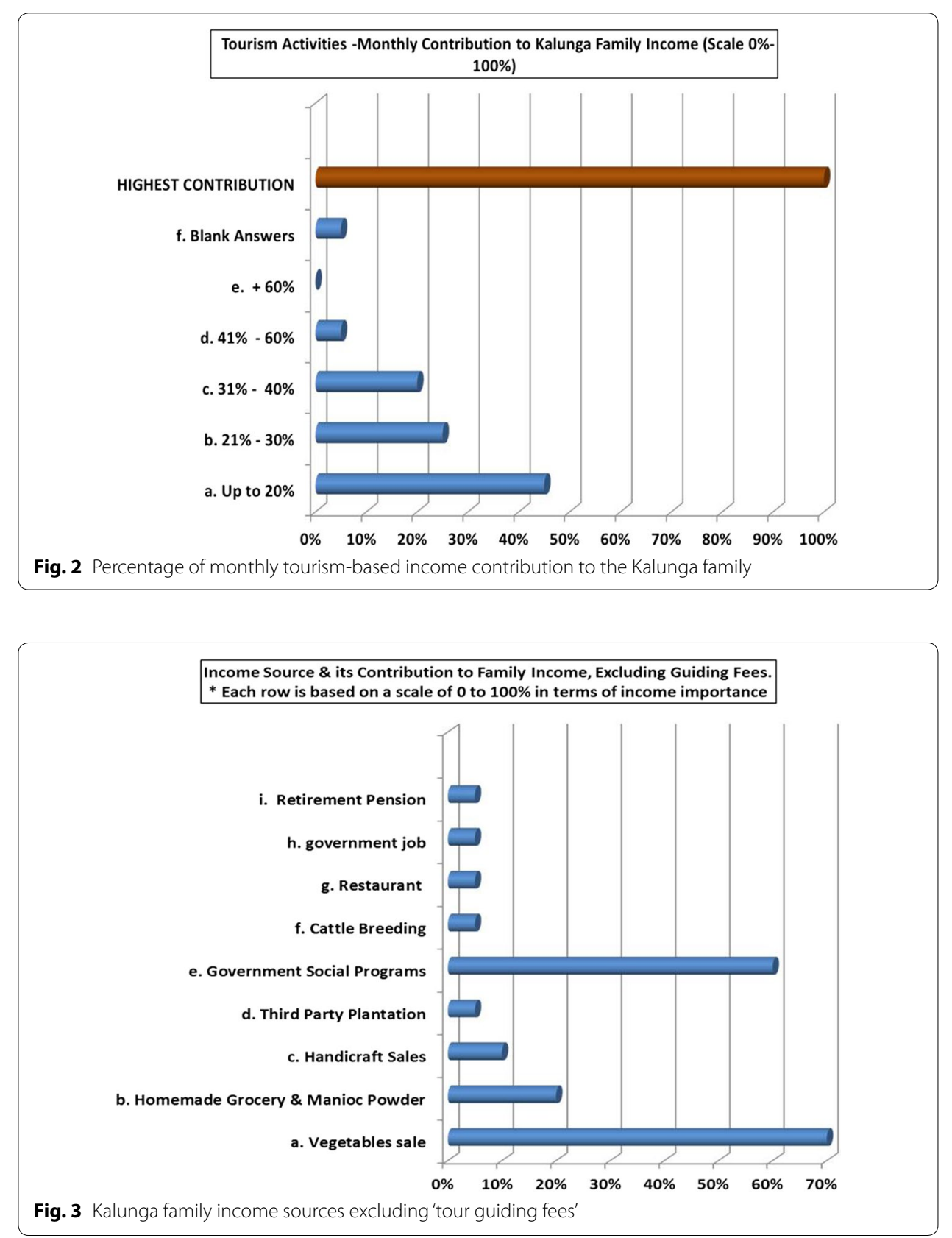

Based on survey research of the Kalunga, the following issues were regarded as advantages for community tourism. These reflective of a local perception of tourism businesses and visitor flow, see Fig. 5 . The Kalunga desire a change in the way tourism has been operationally working. Specifically, they acknowledge the importance of tourism as a drive for improving the community life, communal structures, and landscapes, in terms of: (i) income improvement; cultural valorization; network building; network strengthening; (ii) knowledge, and increased local environmental awareness; support; aid; visitors; (iii) visibility, and capacity. 

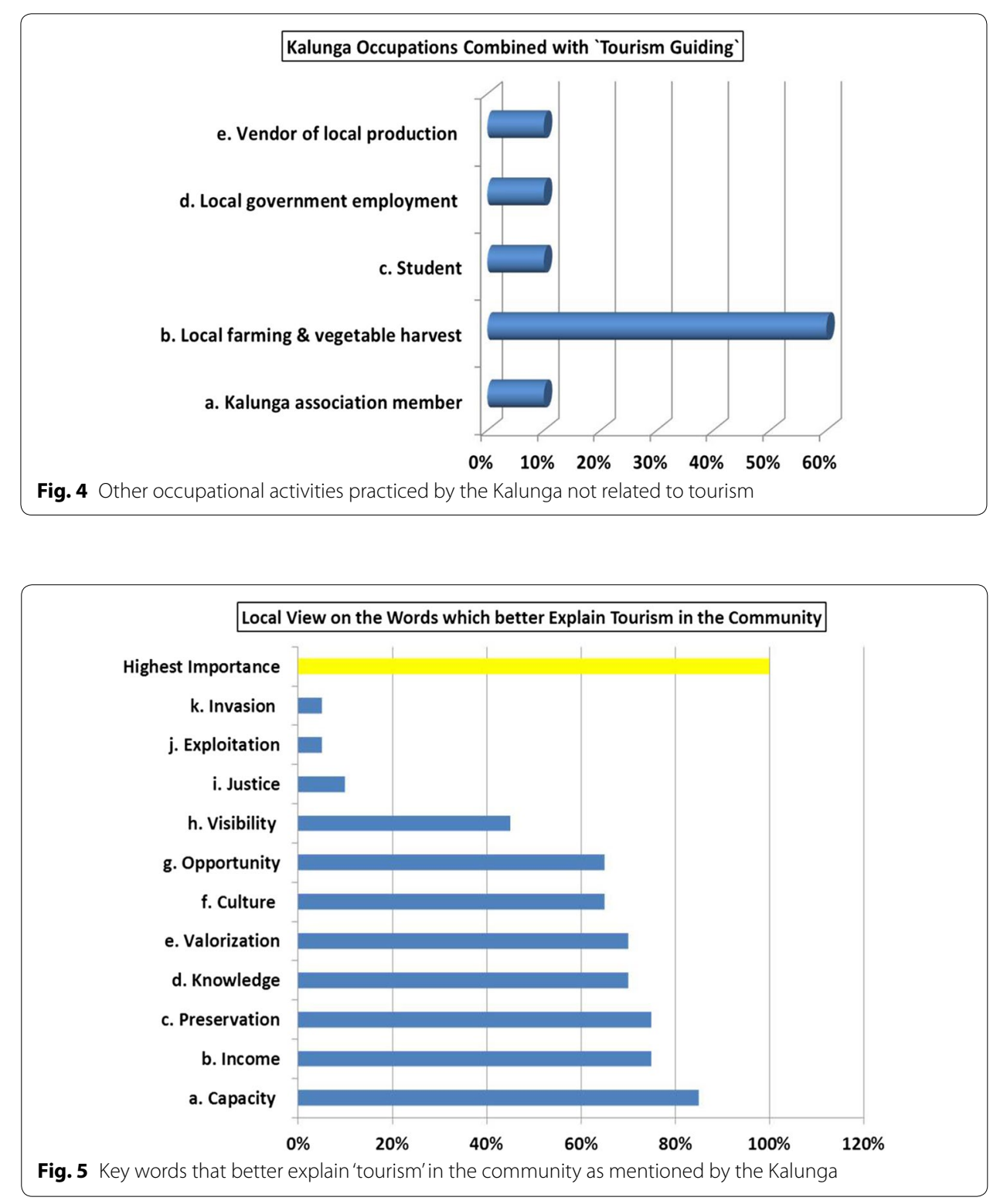

During the fieldwork, informal talks with local residents, and they informed us about the need of a widespread democratization of tourism benefits for the community. It is an uneven activity which benefits few ones more directly involved as it does not have a 'community fee' fairly applied in the communal spaces and structures of the community. Who gets more benefits? $45 \%$ mentioned the 'tourism guides', $35 \%$ stated that 'owners of restaurants' get more benefits, $5 \%$ mentioned the 'Cavalcante City Prefecture', $5 \%$ said that it is the Kalunga Association's President, $5 \%$ stated that the 'local leaders', and $5 \%$ did not answer it. Yet in the field works, it was noted that most Kalunga who support tourism development want a type of financial autonomy for local tourism management, an upgrade in tourism as a community business, in which the follow-ups should ensure enough income generation and financial resources in a way it can be reinvested in the communal spaces of the Kalunga and in the tourism assets. It is thus all about building 
the foundations for an 'ethnically tourism-oriented, financially-sourced, entrepreneurship' in the Kalunga land. In reason of this specific finding, the research set as a chief objective to outline the main fields and framework as an entrepreneurship model proposal for the Quilombola as the means to achieve levels of local development through tourism.

\section{Defining 'ethnic entrepreneurship' within the context of ethno-development}

A leading discussion in tourism literature focuses on 'ethnic entrepreneurship' as a driver for a sustained long-term community development and prolonged income generation. Many of the published articles conceptually approach 'ethnic entrepreneurship' as "a set of connections and regular patterns of interaction among people sharing common national background or migration experiences" (Waldinger et al. 1990) with a direct relationship to 'clustered immigrant ethnic groups' and their related self-building networks and niches (Light et a1. 1993; Razin and Langlois 1996; Fregetto 2004), a fragment of a dominant nationals of a culture (Thornton 1999). Thus, there is not a focus on 'native ethnic groups and their business with cultural assets' or 'indigenous communities'; ratherhas a focus on 'immigrants' and their ways of clustering and knitting themselves in "modern societies" generally occupying a sociocultural dimension in a certain urban business. 'Ethnic entrepreneur' is defined by Yinger (1985) as "a segment of a larger society whose members are thought, by themselves or others, to have common origin and share important segments of a common culture" (p.27). In this context, 'ethnic entrepreneurship' is understood as 'immigrant entrepreneurship'. Despite the interfaces of ethnicity, culture and socioeconomic category, this approach certainly does not apply to the Kalunga context, because immigrant entrepreneurship such as the Italians, Greeks, Lebanese, etc. is a niche of the literature which largely differs from the way the maroon communities were composed in the past by runaway slaves.

Noticeably, other mainstream approach in the literature refered to as 'ethnic entrepreneurship' is one of the associated studies of 'Anthropology of Capitalism' with specific analysis on ethnicity, sustainability, and business, and related market issues and with critical views of neoliberal late capitalism (Rata 2003) and its financial "paroxysms" in face of ecopolitical demands for conservation of nature and of culture, for example (Heffernan and Wragg 2011). Some of these studies deal with the possibilities, achievements, and challenges for implementing and managing a non-conventional entrepreneurship by distinct ethnic groups, which are normally geographic and culturally placed in specific areas or sites, either being urban or jungle in context. This mainstream approach is tightly related to Kalunga and indigenous communities and their business-led initiatives. Some authors make a dichotomy between 'ethnic entrepreneurship' and 'indigenous entrepreneurship' (Peredo et al. 2004; Volery 2007; Lee-Ross and Mitchell 2007).

As for 'entrepreneurship', definitions are drawn from multiple disciplines, such as sociology, management and economics. Its multidisciplinary features make it difficult to develop a singular definition and consensus over it (Simpeh 2011); there is no established definition over what constitutes entrepreneurship because there is no universally accepted definition (Kirby 2003; Chell et al. 1991). Most of the existing definitions usually fall into two major categories: one deals with analysis over behavioral characteristics of entrepreneurs (Wickham 1998), whereas another stream is more centered on the 
development of the entrepreneurship in regard to [business] 'environment' and 'situations' (Zimmer and Scarborough 2005); thus, polarizing its perspectives on 'individuals' or on 'environment', a view rejected by Shane (2003) who advocates on an individualopportunity nexus. That is, environment and individuals are not mutually exclusive for a thriving entrepreneurship, contrary to that they are complementary to each other and thus multi-disciplinary.

Peverelli and Song (2012) provide both a system of classification and analysis of elements which form the essence of an entrepreneurship; their classification is based on three schools of thought on entrepreneurship as described in the literature. The first one focuses on the economic approaches; the second one has an approach on traits, and the third is about social identifiable approaches. With a plethora of definitions for entrepreneurship, Rindova, et al. (2009) brings a more concise one by describing it as "the efforts of an individual or of group(s) of individuals at generating new institutional, social, economic, and cultural environments" (p. 477). We believe, conceptually, that this description serves as groundwork for analyzing the Kalunga's case.

This section will briefly discuss the definition of 'indigenous entrepreneurship' as part of a broader discussion on ethnic entrepreneurship. Both have various intersections that allows one to state that indigenous entrepreneurship-as Kalunga entrepreneurshiplies in the dimension of an ethnic entrepreneurship, which is itself under the auspices of the overarching concept of ethnodevelopment (Lima 2014a, b; Nieuwkoop and Uquillas 2000), if Kalunga values are to be respected. That is, an ethnic entrepreneurship in the context of an 'ethnodevelopment' which does not imply at any instance a sort of commodification of culture and of natural resources (Bonfil Batalla 1982).

Commodification of culture has been an investigated topic with critical approaches, as much as spectacularisation of culture (Hellier-Tinoco 2014; Martineau and Ritskes 2014) by researchers who seek to show the drawbacks, the downsides of misusing people`s traditional and unique ways of living and understanding of their contiguous world (Macleod 2006; Medina 2003). As discussed by Maccarrone-Eaglen (2009), debates over the use of culture in the tourism sector for cashing out on business pervade the literature with an array of criticisms, where one's traditional life is "imaged and transformed into saleable products" (Robinson 1999, p. 11), a type of commoditization of "cultural practices perpetuates the long history of exoticism display and spectacularisation for economic return" (Hellier-Tinoco 2014, p. 76).

Culture is identified by Doherty (2000) as a bonding element of individuals of a society by symbolism that is broadly accepted and adopted by those clustered as group, and culture is extensively (re)defined and cited by many authors (Birukou et al. 2013; Jenks 1995; Kroeber and Kluckhohn 1952). Greenwood (1989) postulates that culture can be perversely appropriated by many forms, including by tourism sector,

Treating culture as a natural resource or a commodity over which tourists have rights is simply perverse, it is a violation of the people's cultural rights...Thus commoditization of culture in effect robs people of the very meanings by which they organize their lives (p. 179).

With regards to indigenous entrepreneurship, it is initially necessary to explain the term indigenous. Etymologically it is rooted in the Latin, and the word means native or 
born within (Klein 1966). According to Merriam Webster dictionary online, 'indigenous' is used describe a person or people living, or existing naturally in a particular region or environment and, or, thing(s) within the same context, for example, indigenous land, indigenous food, indigenous people. The Oxford Dictionary online defines it as "originating or occurring naturally in a particular place; native", as in indigenous community, native community. The International Labor Organization (1991) describes 'indigenous people' as,

Peoples in independent countries who are regarded as indigenous on account of their descent from the populations which inhabited the country, or a geographical region to which the country belongs, at the time of conquest or colonisation or the establishment of present State boundaries and who, irrespective of their legal status, retain some or all of their own social, economic, cultural and political institutions.

Kalunga people may not lie under the category of indigenous people as they are a generation of descendants of run-away slaves who settled in remote areas of Goias, and they are racially composed of black individuals and, or, of mixed race of blending black and local native Indians. Kalunga can be properly described as a racially black-mixed composed group; thus, an ethnically defined group. With a different understanding, Blaser et al. (2004) say that "any given people, ethnic group, or community may be described as 'indigenous' in reference to some particular region or location that they see as their traditional tribal land claim" (p. 53-56). This approach assumes the interwoven nature that some individuals have to a native land, or to a land or site to which they have strong feelings of belonging to.

Some 'bonding elements' which harness members of a 'native, 'ethnic', or 'indigenous' group or community can be identified and are inherently part of the analysis on 'ethnic entrepreneurship' of the Kalunga. The 'linking elements' can be non-material attributes and physical artifacts such as the territory, identity, traditions, beliefs, customs, religion, culture, festivals, language, gastronomy, religion, world views, dances, songs, tales, stories, dreams, architectural style, nature, flora and fauna, landscape, the ecosystem, traditional knowledge, and all elements which pool themselves as essential to a group cultural heritage as already largely cited an array of UNESCO documents (Ahmad 2006).

Ethnodevelopment-sustained by ethnic identities and ethnic alliances-has thus emerged as a proposal in contrast and resistance to neoliberal commodification and appropriation of 'peoples' and 'their natural assets' (Hogue and Rau 2008). Within this perspective, a diagram is outlined so as to illustrate the key factors that should be taken into account at the moment of designing an ethically oriented operational system for enterprises and production by traditional groups in an Ethnodevelopment context (refer to Fig. 6). The main leading ideas and drivers of such an enterprise and product system are those related to advocating ethnic values and conserving natural assets in an attempt to include 'sustainability' as a reasoning factor, as well as to set goals for ethnically strengthening ethnic enterprises by achieving levels of resistance vis-à-vis any overwhelming neoliberal installation and forms of group appropriation.

That is, business is a core element, but people and their land (and natural resources) cannot be subjugated by 'westernised capitalist' trends and mercantile rules. Entrepreneurship is thus thought to lead ethnically structure enterprises and production into 


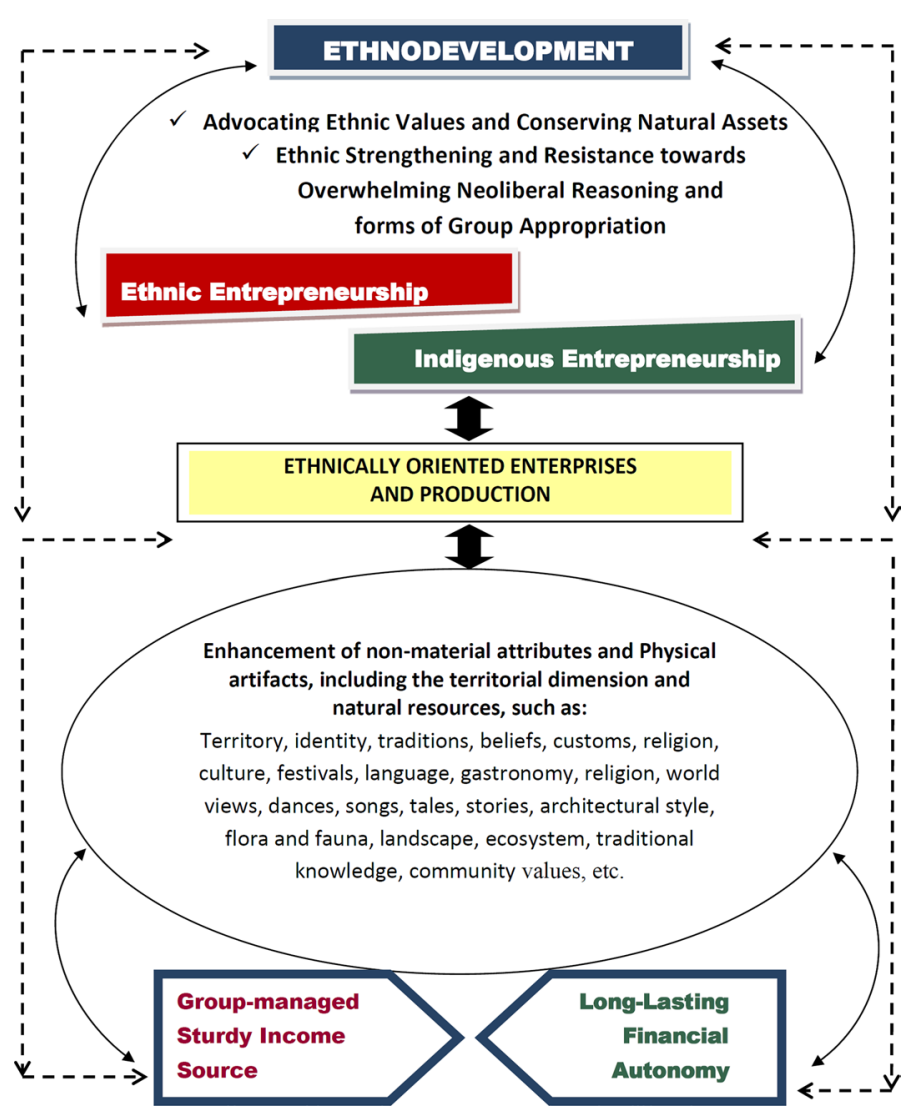

Fig. 6 Ethnically oriented enterprises and production within the scope of an ethnodevelopment: advocacy for the unprivileged ones

'steady income sources' and 'long-lasting financial autonomy', so those pertinent groups are financially enabled to govern their business initiatives (Fig. 6). A substantial context change can lead towards a more economic and financially sounded tourism for the Kalunga, rather than having tourism as a rhetorical allegory, unable to break up with social imbalances and patchy distribution of income.

Instances of established functional quilombola/quilombo enterprises can be found in the pertinent literature with studies showing off the main achievements and structure of this sort of 'community-based business', ethnically oriented, that is, underpinned by 'ethnic', 'market,' 'financial', 'social' and 'sustainable' issues and concerns. For example, the Quilombola community of Mandira in Cananeia, state of Sao Paulo, has been cooperatively developing an sustainably managed business based on oyster production, dressmaking, sewing, handicraft and heritage tourism. According to Lucio (2013), due to environmental law approved in the 1970s the quilombola community needed to restructure themselves in order to avoid disintegration of its land and sociocultural fabric; with institutional support the community was involved in an entrepreneurial model built on a preservationist platform and managed as an organizational cooperative.

Of note, there is some institutional limelight for the maroon entrepreneurships in Brazil which can further reinforce ongoing social inclusion policies and projects, and ensure 
racial justice and balances as stated at and guarantee by the Brazilian 1988 Constitution. In August 2013, Small Business Support Service (SEBRAE), launched the 'Brazil Afro-Entrepreneur Project' aiming at capacity building and institutional provision for 'maroon communities' and their local business initiatives. In February 2015, the Brazilian Minister for Agrarian Development (MDA) launched a 'Quilombos Product Certification' as a tool to add value to maroon products with an emphasis on sustainability; social, environmental responsibilities; valorization of local culture, and, certainly, valuing a regional production as a source of income and as the means to promote local development. Table 1 shows some examples of Quilombo entrepreneurships which reconnects a 'rural economy' to an 'urban economy', and are mostly related to 'family agriculture arrangements'.

\section{A proposed model for an ethnic-based Quilombola (Kalunga) entrepreneurship}

The following two interconnected diagrams (Figs. 7 and 8) are a synthesis of the key points discussed in the research, gathering the key elements which should be taken into account for outlining 'an ethnic-based quilombola entrepreneurship model proposal' in terms of an ethnic tourism planning and management. The Model is divided into two major stages of Planning and Management (Figs. 7 and 8), and they are cyclical in terms of information and data production in a continuum of actions which involves five steps: access, design, implementing, monitoring, and optimizing. The planning stage is mostly outlined in regard to information and data access (access) and the designing of action plans (Design).

The 'Access Step' (Fig. 7) involves the selections of tools for data collection such as 'community mapping', 'community consultation', 'survey existing data, 'local working group', etc. With these tools, it is expected to identify key elements such as 'community values and views', 'overall community demands', 'trade and stakeholders interests (and support),' 'government and organizational support'; 'market demands and potential', 'financial sources', as well as 'demands for capacity building and for structural facilities'.

The Design Step (Fig. 7) is an attempt to congregate the key stakeholders' views, interests and demands with those of the Kalunga community in their ethnic-based tourism projects in a way to easing mutual dialogues, and reciprocal understanding, building up a participatory community-based platform. The pertinent stakeholders are the government bodies and agencies, the civil society, and representatives of the tourism trade, but the list is not exhaustive. The proposed 'ethnic-based tourism entrepreneurship' for the Quilombola can be either operationalised by one or a mix of the following models: 'family-based,' 'group-based,' 'community-based', Cooperatives, Associations; Multiple Stakeholders System; Public Partnered, Private Partnered, Public-Private Partnered (Fig. 7). The Kalunga community already has a settled association, the Associacao Quilombola Kalunga, notwithstanding it needs to be strengthened with more institutional support, particularly to address its plans for entrepreneurship projects.

The 'Management Stage' (Fig. 8) has an 'Implementing Step' which requires actions for Kalunga reality change, and they translate the challenges to be faced for achieving it, particularly in regard to a long-lasting 'financial emancipation'. As the means to achieve expected outcomes actions towards 'capacity building programs', 'group awareness 


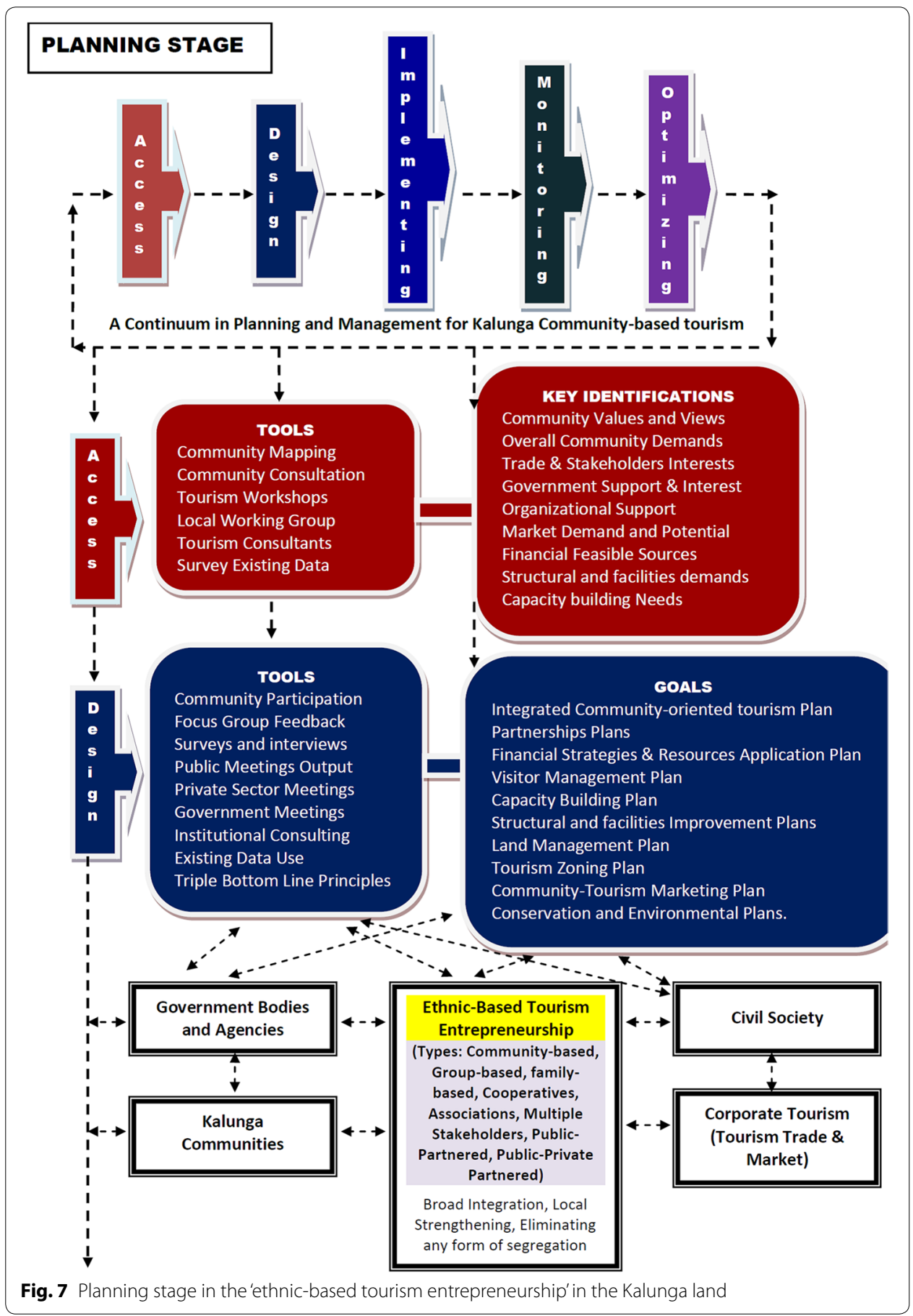

raising,' 'partnership set', 'investment channels creation (or development)', and 'integration of the community' are required. The expect outcomes in benefit of the Kalunga Quilombola are: 'human capital formation', 'strengthened social capital', 'knowledge transfer and sills acquisition,' 'added value to services and products', 'getting external support', 'investments on the community tourism structures and current (and future) equipments', 'community empowerment', as well as 'successful marketing achievements' by 


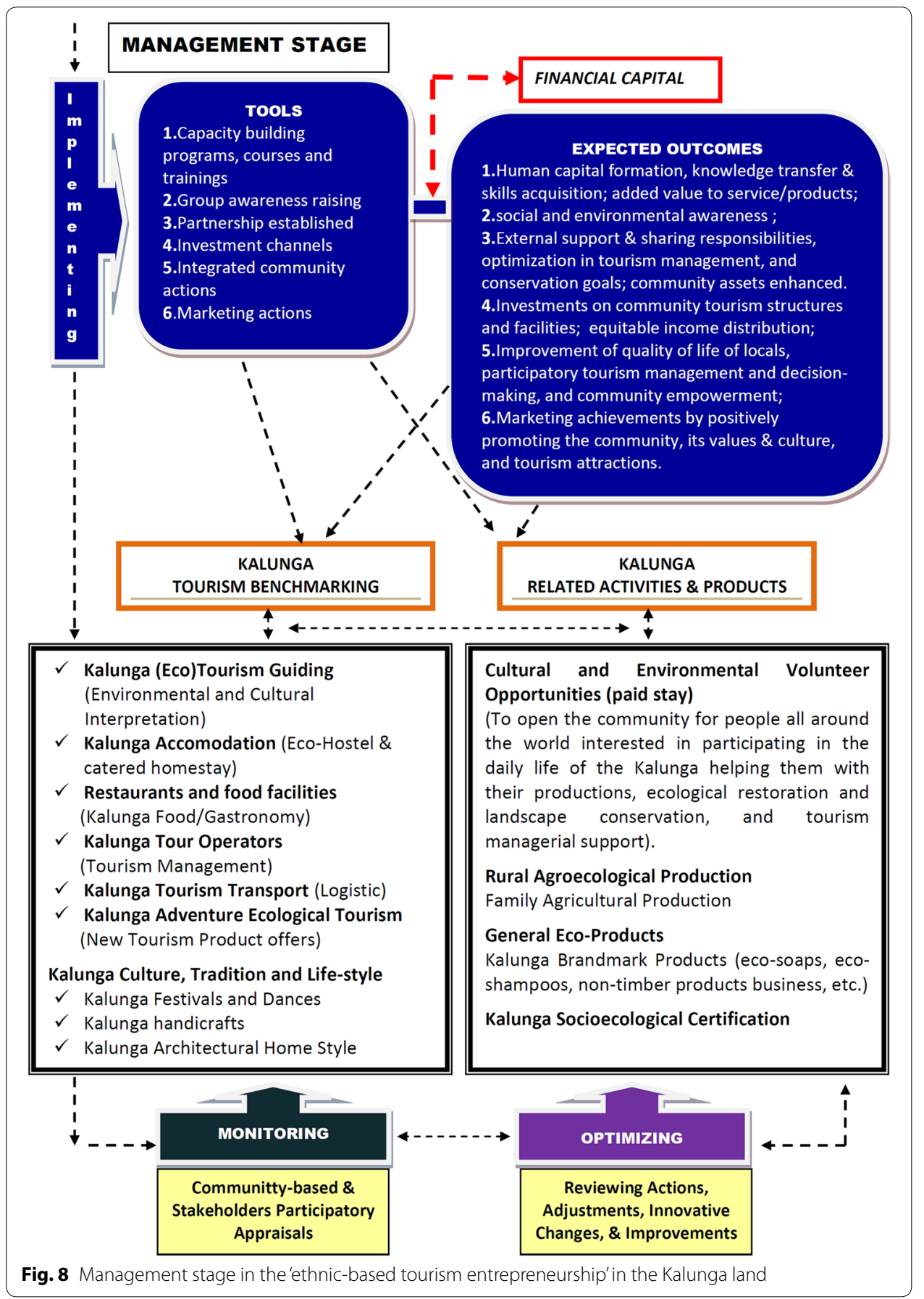

promoting 'Kalunga values and culture', and of course, their natural assets and tourism attractions (Fig. 8).

The 'Management Stage' encompasses two more stages in the ethnic-based tourism entrepreneurship which are the 'Monitoring' with participatory community appraisals and the 'Optimizing State' for reviewing actions, improvements, and innovative actions. This model has cyclical stages and steps which can lead the community and engaged stakeholders to (re)planning issues and, or, making changes in the managerial 
proceedings, as well as they can serve for building up a 'creative economy' as one emerging from within a community regarding locals' views and plans (Marinho 2013).

The Kalunga products and services can be various in tourism development such as guiding, accommodation providers, food and traditional meal facilities, tour operator, transport, eco-adventure tourism products development, events (festivals, dances), fairs (gastronomy, handicraft, etc.), or homestay in traditional houses. The roll of opportunities for community income generation is not exhaustive and can include environmental volunteer programs (paid one), rural agroecological production, eco-products, and Kalunga certification (Fig. 8). It is worth noting that 'partnerships' play a key role in community development, particularly in capacity building, instruction, and guidance in many fields. The Kalunga already have received support from many institutions, including Cavalcante City Prefecture, SEBRAE, PETROBRAS, Banco do Brasil, and from teams of researchers, from the LABOTER/IESA of the Federal University of Goias, UFG, and the Center of Excellence in Tourism, CET, of the Brasilia University, UnB, just to mention fewer ones. But, again, more need to be done for the Kalunga particularly in terms of skills with hospitality, management, heritage and environmental interpretive guiding, as well as basic notions on 'accounting'.

In regard to Quilombola financial emancipation and institutional support, it is worth noting that in November of 2007 it was inaugurated the first Quilombola Bank of Brazil in Alcantara, a city of 22,000 inhabitants, in the Maranhao State. This peculiar and innovative financial ethnically oriented institution has social money, called Guara, acknowledged and used locally only in operational value terms and change. With an initial capital of BRL 50,000 (about US\$ 28,000), former slaves descendents of the Quilombolas can get low-tax loans and other benefits. The Ethnic Community Bank is the outcome of an Inter-Institutional Partnership between the Ministry of Labor, and the Maranhao State Labor Agency. The goal is to expand it by inaugurating 20 new bank branches in Brazil (Ministerio do Trabalho, Boletim PPDLES, 2007).

This example reveals how promising are the financial opportunities for the Quilombola communities as they are contemplated by institutional and government interventions, support, and mediation, not to mention the possibilities with the private sector through partnerships. The Kalunga can also further benefit of this type of 'financial capital', which can be broadly understood as "financial resources available to invest in community capacity building, to underwrite businesses development, to support civic and social entrepreneurship, and to accumulate wealth for future [...] development" (Department of Sociology, Iowa State University 2008), as part of a set of 'bonding' and 'bridging' community capitals (Flora and Thiboumery 2006; Flora and Flora 2004).

\section{Conclusion}

The investigation reveals a very positive impact that nature-based tourism practiced and managed by the Kalunga communities located in remote areas that have a weak economic system with little money in circulation amongst the locals. The increasing number of visitors and the involvement of locals in tourism management and guidance have been a novelty, and this momentum have resulted in a broad and encompassing enthusiasm among them, with an obvious improvement of their self-esteem. There is a strong feeling of pride among the locals of belonging to the Kalunga site (Land) as 
discussed in the studies on identity, cultural resistence, territoriality and ethnodevelopment (Lima 2014a, b; Lima and Kumble 2015; Lima and Weiler 2015; Marinho 2008, 2014; Deus e Castro 2014). The Kalunga, as a maroon clustered group, needs to develop a sort of nature-based tourism with levels of economic self-reliance in terms of income generation and financial capital to be invested in their communal assets. Without having a financial emancipation, the Kalunga Quilombola will face drawbacks in their local development. Those communities need institutional support to build up their ethniceconomic foundations so they will have the means to better manage their social and environmental assets.

An ethnic-entrepreneurship model has been proposed as a tool for achieving better standard of living through a participatory and collaborative tourism. Notwithstanding, it is highlighted that tourism cannot be a stand-alone model taken as the only solution for a financial emancipation. Instead, tourism activities are one of the numerous pathways for the economic purposes. An ethnic-tourism entrepreneurship model (ETMD) should be implemented by regarding tourism as a complementary activity to others which are practiced or can be practiced by the Kalunga in their lands. Despite the skepticism of Blackstock (2005) on a community-based development considering it as naïve and unrealistic on the grounds that this type of developmental model ignore the internal dynamics of communities, the external barriers and the inequalities between developers and community members (p. 45), the possibilities for an overall Kalunga community empowerment through ecotourism entrepreneurship are reliant on the financial and institutional support and assistance which can be channeled into community projects, combined with a progressive local capacity building. Forms of partnerships between the community and private developers may also speed up this empowerment with the implementation of tourism business by seeking community inputs on the nature of the structure.

\section{Authors' contributions}

$I B L, E F C$ were responsible for designing the project; PK, EFC, IBL, RDM, and MGA participated in the literature review. IBL, MGA, PK, LCGF, and RDM participated in the fieldwork and technical visits for data collection. EFC, PK, and LCGF helped to improve methodology; IBL and PK provided the first draft with analysis and results. IBL, PK, MGA, EFC, RDM, and LCGF participated in the final draft of the article and in its revision. PK provided English proofreading. All authors read and approved the final manuscript.

\footnotetext{
Author details

${ }^{1}$ School of Business and Tourism, Southern Cross University, SCU, Gold Coast Campus, Gold Coast 4225, QLD, Australia. 2 MultiAmazon/State University of Roraima, UERR, and RECINATUR, Rua Sete de Setembro, 291, Canarinho, Boa Vista CEP 69303-530, Roraima, Brazil. ${ }^{3}$ Department of Land Use and Improvement, Faculty of Environmental Sciences, Czech University of Life Sciences, CULS, Prague, Czech Republic. ${ }^{4}$ Laboter/IESA, Federal University of Goias, UFG, Campus II Samambaia, Goiania, Goias 74001-970, Brazil.
}

\section{Acknowledgements}

The paper was the result of a research financially supported by the Goias State Research Funding Foundation, FAPEG, and by the CNPQ, Public Call DCR-05/2009, and logistically supported by the Laboter/IESA, of the Federal University of Goias, UFG, Brazil.

Received: 26 November 2015 Accepted: 5 January 2016

Published online: 20 January 2016

\section{References}

Ahmad Y (2006) The scope and definitions of heritage from tangible to intangible. Int J Herit Stud 12(3):292-330 Americo MC (2010) Quilombo Ivaporunduva: as relações estabelecidas com o território e os significados atribuídos ao trabalho que gera renda. Revista identidade! 15(1): 65-75 
Amorim WM (2015) O dificil trajeto pela posse da terra. In: de Almeida MG (ed) O territorio e a comunidade Kalunga: quilombolas em diversos olhares. Editora UFG, Goiania, pp 69-90

Aref F, Redzuan MB (2009) Community capacity building for tourism development. J Hum Ecol 27(1):21-25

Atkinson R, Flint J (2001) Accessing hidden and hard-to-reach populations: snowball research strategies. Social Research Update. Deapartment of Sociology. University of Surrey. Available at, http://sru.soc.surrey.ac.uk/SRU33.pdf. Accessed 20 Nov 2015

Beeton S (2006) Community development through tourism. Lands Link/CSIRO Publishing, Collingwood

Begnini E (2003) Ecoturismo e a questão do desenvolvimento sustentável em São João d'Aliança no Nordeste Goiano. Unpublished dissertation. Centro de Excelência em Turismo, Universidade de Brasília—UnB, Brasil

Beni MC (2006) Politica e Planejamento de Turismo no Brasil. Aleph, Sao Paulo

Bennett N, Lemelin RH, Johnston M, Nation LKD (2010) Using the social economcy in tourism: a study of national park creation and community development in the Northwest Territories, Canada. J Rural Community Dev 5(1/2):200-220

Birukou A, Blanzieri E, Giorgini P, Giunchiglia F (2013) A formal definition of culture. In: Sycara K, Gelfand M, Abbe A (eds) Models for intercultural collaboration and negotiation. Springer, Amsterdam

Blackstock KL (2005) A critical look at community based tourism. Commun Dev J 40(1):39-49

Blackwell A, Colmenar R (2000) Community-building: from local wisdom to public policy. Public Health Rep 115(2/3):161-166

Blaser M, Feit HA, McRae G (2004) In the way: indigenous peoples, life projects, and development, IDRC

Bonfil Batalla G (1982) El Etnodesarrollo: sus Premises Jurídicas, Políticas y de Organización. In: Bonfil Batalla G (ed) America Latina: Etnodesarrollo, Etnocídio. FLACSO, San Jose, Costa Rica, pp 133-145

Brasileiro ILG, Pena LCS (2015) Desafios do turismo na terra de pretos. In: de Almeida MG (ed) O territorio e a comunidade Kalunga: quilombolas em diversos olhares. Editora UFG, Goiania, pp 230-252

Brito-Neto de JCB (1995) L'information des exclus: l'experience des Calungas au bresi. Unpublished doctoral thesis. Enjeux Sociaux Et Technologies de La Communication

Brito-Neto de JCB (2002) A Informação na Construção da Cidadania entre os Calungas'. Trabalho apresentado no NP13Núcleo de Pesquisa Comunicação e Cultura das Minorias, XXV Congresso Anual em Ciência da Comunicação, Salvador/BA, 4/5

Buckley R, Pickering C, Weaver DB (2003) Nature-based tourism, environment and land management. Cabi Publishing Cambridge

Chell E, Haworth J, Brealey S (1991) The Entrepreneurial Personality: Concepts. Cases and Categories, Routledge

da Silva RE, Carvalho KD (2010) Ethnic tourism in quilombolas communities: perspective for the ethnodevelopment in Filipa (Maranhão, Brazil). Turismo e Sociedade 3(3):203-219

de Almeida MG (2010) Territórios de Quilombolas: pelos vãos e serras dos Kalunga de Goiás—patrimônio e biodiversidade de sujeitos do Cerrado. Revista Ateliê Geográfico 1(9):36-63

de Almeida MG (2014) Etnodesenvolvimento e turismo nos Kalunga do Nordeste de Goias. In: de Lima IB (ed) Etnodesenvolvimento e Gestao Territorial: Comunidades Indigenas e Quilombolas. Editora CRV, Curitiba

de Almeida MG (ed) (2015) O territorio e a comunidade Kalunga: quilombolas em diversos olhares. Editora UFG, Goiania

de Baiocchi MN (1999) Kalunga: Povo da Terra. Brasilia, Secretaria de Estados dos Direitos Humanos, Ministry of the Justice

de Deus JAS (2014) Protagonismo politico, etnodesenvolvimento e processos de reterritorializacao de comunidades Quilombolas, em Curso, no Vale do Jequitinhonha, MG. In: de Lima IB (ed) Etnodesenvolvimento e Gestao Territorial: Comunidades Indigenas e Quilombolas. Editora CRV, Curitiba, Parana, Brasil

Lima IB de (2011) The micro geopolitics of ecotourism: the intricacies of discursive constructions, power relations and partnership models in planning, promotion and management of (eco)tourism. CreateSpace, North Charleston

Lima IB de (ed) (2014a) Etnodesenvolvimento e Gestao Territorial: Comunidades Indigenas e Quilombolas. Editora CRV, Curitiba

Lima LNM de (2014b) O Cerrado como territorio-lugar de resistencia e de identidade das comunidades Kalunga. In: Lima I (ed) Etnodesenvolvimento e Gestao Territorial: Comunidades Indigenas e Quilombolas. Editora CRV, Curitiba, Parana, Brasil

Lima IB de, Kumble P (2015) Intervencoes etnoterritoriais e sociais: os avancos no desenvolvimento comunitario Kalunga com o (eco)turismo. In: de Almeida MG (ed) O territorio e a comunidade Kalunga: quilombolas em diversos olhares. Editora UFG, Goiania, pp 191-229

Doherty K (2000) 'Going it alone': the discursive construction of identity and enterprise culture. Unpublished doctoral thesis, University of Sheffield, UK

Falk I, Harrison L (1998) Community learning and social capital: "just having a little chat". Journal of Vocational Education and Training 50(4):609-627

Faria de IF (2005) Ecoturismo: etnodesenvolvimento e inclusao social no Amazonas (Ecotourism: ethnodevelopment and social inclusion in Amazonas). PASOS - Revista de Turismo e Patrimonio Cultural 3(1): 63-77

FGV_Fundação Getúlio Vargas (2010) Plano de Desenvolvimento Integrado do Turismo Sustentável (PDITS)—Polo da Chapada dos Veadeiros. Sao Paulo, Brasil. (Unpublished report)

Fink A (2003) The Survey Handbook. The survey kit, SAGE, London

Flora CB, Flora JL (2004) Bonding and bridging social capital in communities with Latino In-Migrants. Cambio de Colores (Change of Colors): Latinos in Missouri: Gateway to a New Community. University of Missouri, St. Louis, USA

Flora CB, Thiboumery A (2006) Community capitals: poverty reduction and rural development in dry areas. Ann Arid Zone 45(3/4):1-2

Franco RD, Tarrega MCVB (2015) A odisseia rumo a protecao do territorio Kalunga. In: de Almeida MG (ed) O territorio e a comunidade Kalunga: quilombolas em diversos olhares. Editora UFG, Goiania, pp 91-112

Fregetto E (2004) Immigrant and ethnic entrepreneurship: a US perspective. In: Welsch HP (ed) Entrepreneurship: the way ahead. Routledge, New York, pp 253-268 
Fundação Getúlio Vargas. Governo do Estado de Goiás - Agetur. http://www.goiasturismo.go.gov.br/pdits/Veadeiros.pdf. Accessed 26 April 2011

Given LM (2008) The SAGE encyclopedia of qualitative research methods. SAGE, London

Greenwood D (1989) Culture by the pound: an anthropological perspective on tourism as cultural commodification. In: Smith V (ed) Hosts and guests: the anthropology of tourism. Pennsylvania University Press, USA

Guest G, MacQueen KM, Namey EE (2011) Applied thematic analysis. SAGE, London

Hart R (1985) Slaves who abolished slavery, vol 2. The Herald Kingston, Jamaica

Heffernan N, Wragg DA (2011) Culture, Environment and Ecopolitics. Cambridge Scholar Publishing, Newcastle

Hellier-Tinoco R (2014) Embodying touristic Mexico: virtual and erased indigenous bodies. In: C Pearce et al. (ed) Meet Me at the Fair: a World's Fair Reader. Self-edited

Hogue EM, Rau P (2008) Natural resources commodification, and neoliberalism in andean Peru. Urban Anthropol 37(3/4):283-327

Jenks C (1995) Culture. Routledge, London

Johnson PA (2010) Realizing rural community based tourism development: prospects for social-economy enterprises. J Rural Community Dev 5(1/2):150-162

Kilpatrick S (2000) Community learning and sustainability: practice and policy. Keynote address to First Conference on the Future of Australia`s Country Towns, LaTrobe University, Australia

Kirby A (2003) Entrepreneurship. McGraw-Hill Education, Berkshire

Klein E (1966) A Comprehensive Etymological Dictionary of the English Language, vol I A-K. Elsevier Publishing Company, New York

Kroeber AL, Kluckhohn C (1952) Culture: a critical review of concepts and definitions. Pap Peabody Mus 47:643-656

Lee-Ross D, Mitchell B (2007) Doing business in the Torres Straits: a study of the relationship between culture and the nature of indigenous entrepreneurs. J Dev Entrepreneurship 12(2):199-216

Light I, Bhachu P, Karageorgis S (1993) Migration networks and immigrant entrepreneurship. In: Light I, Bhachu P (eds) Immigration and Entrepreneurship. Transaction Publishers, New Brunswick, pp 25-51

Lima I, Weiler B (2015) Indigenous protagonism in tourism operations and management in Australia, Brazil, and New Zealand. ASR CMU J Soc Sci Humanities 2(1):7-37. doi:10.12982/cmujASR.2015.0003

Lindberg K, Hawkins DE (1998) Ecotourism: a guide for planners and managers, vol. 2, Ecotourism Society, North Bennington, Vermont

Little PE (2002) Etnodesenvolvimento local: autonomia cultural na era do neoliberalismo global. Tellus 2(3):33-52

Lucio CF (2013) Natureza e cultura como commodities : um estudo antropológico sobre três iniciativas de empreendedorismo étnico de cunho sustentável na comunidade quilombola do Mandira, Cananéia/SP. Unpublished doctoral Thesis, IFCH, UNICAMP, Sao Paulo

Maccarrone-Eaglen A (2009) An analysis of culture as a tourism commodity, Tour Cult Commun 1-9. doi:10.3727/109830 409X12596186103879

Macleod D (2006) Cultural commodification and tourism: a very special relationship. Tourism, Culture Commun 6(2):71-84

Marinho TA (2008) Identidade e territorialidade entre os Kalunga do Vão do Moleque. Dissertação (Mestrado em Sociologia)_Programa de Pós-Graduação em Sociologia_UFG

Marinho TA (2013) A economia criativa e o campo etnico-quilombola: o caso Kalunga. Ciencias Sociais Unisinos 49(3):237-250

Marinho TA (2014) Cultura Kalunga: entre a territorialidade e o culturalismo. In: de Lima IB (ed) Etnodesenvolvimento e Gestao territorial: comunidades indigenas e quilombolas. Editora CRV, Curitiba

Martineau J, Ritskes E (2014) Fugitive indigeneity: reclaiming the terrain of decolonial struggle through Indigenous art. Decolonization: indigeneity. Educ Soc 3(1):1-12

McKercher B, du Cros H (2002) Cultural tourism: the partnership between tourism and cultural heritage management. Harworth Press, New York

MDA/SDT_Agrarian Development Ministry (2010) Territórios Rurais Região Centro-Oeste. Ministério do Desenvolvimento Agrário, Brasília

Medina L (2003) Commoditizing culture tourism and Maya identity. Ann Tour Res 30(2):353-368

Meneses UTB (2002) Os "usos culturais" da cultura: contribuição para uma abordagem crítica das práticas e políticas culturais. In: Yázigi E (ed) Turismo, Espaço, Paisagem e Cultura. Hucitec, Sao Paulo

Miral C, Kaygalak S, Ersoy R (2013) A casa study of ethnic minorities as tourism entrepreneurs: their involvement in sustainable tourism development. Turizam 17(3):131-144

Molloy A, McFeely C, Connolly E (1999) Building a social economy for the new millenium. Guildhall Press, Derry Northern Ireland

Moore A, Brooks R (1996) Community learning organisations. In: Watkins K, Marsick V (eds) Creating the learning organisation. American Society for Training and Development, Virginia

Orams MB (2002) Marine ecotourism as a potential agent for sustainable development in Kaikoura, New Zealand. Int J Sustain Dev 5(3):338-353

Pare ML, Oliveira LP, Velloso AD (2007) A educação para Quilombolas: experiências de São Miguel dos Pretos em Restinga Seca (RS) e da Comunidade Kalunga do Engenho II (GO). Cadernos Cedes 27(72):215-232

Peredo AM, Anderson RB, Galbraith CS, Honig B, Dana LP (2004) Towards a theory of indigenous entrepreneurship. Int J Entrepreneurship Small Bus 1(1/2):1-19

Peverelli PJ, Song J (2012) Chinese entrepreneurship: a social capital approach. Springer, London

Ramos LMJ, de Almeida MG (2014) Lugares de memoria em trilhas interpretativas: a integracao entre cultura e natureza na visitacao da comunidade Kalunga do Engenho II. In: Lima I (ed) Etnodesenvolvimento e Gestao Territorial: Comunidades Indigenas e Quilombolas. Editora CRV, Curitiba

Rata E (2003) Late Capitalism and Ethnic Revivalism,'A New Middle Age? Anthropol Theory 3(1):46-64

Razin E, Langlois A (1996) Metropolitan characteristics and entrepreneurship among immigrants and ethnic groups in Canada. Int Migrat Rev 30(3):703-727 
Rindova V, Barry D, Ketchen D (2009) Entrepreneurship as emancipation. Acad Manag Rev 34:477-491

Robinson M (1999) Cultural conflicts in tourism: inevitability and inequality. In: Robinson MM, Boniface P (eds) Tourism and cultural conflicts. CABI Publications, Oxon, UK, pp 1-32

Schianetz K, Kavanagh L, Lockington D (2007) The learning tourism destination: the potential of a learning organisation approach for improving the sustainability of tourism destinations. Tour Manag 28:1485-1496

Schwartz SB (1979) The Mocambo: slave resistance in Colonial Brazil. In: Price R (ed) Maroon societies. Anchor Press, Doubleday, pp 202-225

SEPPIR - Secretaria de Promoção da Igualdade Racial (2008). Department for the Promotion of Racial Equity Policies (SEPPIR) (http://www.seppir.gov.br/acoes/pbq). Accessed 26 Apr 2011

Shane S (2003) A General Theory of Entrepreneurship: The Individual-Opportunity Nexus. Edward Elgar, London

Silva J, Campanhola C (1999) Panorama do turismo no espaço rural brasileiro. In: Oliveira de CGS (ed). Anais do Congresso Brasileiro de Turismo Rural. Piracicaba: FEALQ

Simpeh KN (2011) Entrepreneurship theories and empirical research: a summary review of the literature. Eur J Bus Manag $3(6): 1-9$

Singh S, Timothy DJ, Dowling R (2003) Tourism in destination communities. Cabi Publishing, Cambridge

Sirico HLA (2008) Análise do turismo e seus impactos socioculturais na comunidade Kalunga, Goiás. Unpublished thesis. UNESP. Rosana_SP. http://biblioteca.rosana.unesp.br/upload/HugoSirico.pdf. Accessed 15 April 2011

Sofield THB (2003) Empowerment for sustainable tourism development. Pergamon, Amsterdam

Stavenhagen R (1985) Etnodesenvolvimento: uma dimensão ignorada no pensamento desenvolvimentista. Tempo Brasileiro. Anuario Antropologico 84:13-56

Tapia KRL, Trujillo CA (2014) Como hacer proyectos exitosos de turismo comunitatio. Conhisremi, Revista Universitaria de Investigacion y Dialogo Academico 12(2/3):28-57

Taylor B, Sinha G, Ghoshal T (2008) Research methodology: a guide for researchers in management and social sciences. Prentice-Hall of India, New Delhi

Thornton PH (1999) The sociology of entrepreneurship. Annu Rev Sociol 25:19-46

Topolsky J (1997) On target, on task, on reflection: the culture of learning communities, Plenary of the International Conference Community Development Society, 28 July, Athens, Georgia, USA

Trimble JE, Fisher CB (2006) The handbook of ethical research with ethnocultural populations and communities. Sage Publications, California

Ungarelli DB (2009) Comunidade Quilombola Engenho II: Cultura, Produção de Alimentos e Ecologia de Saberes. Unpublished Master thesis. Universidade de Brasilia (UnB). http://repositorio.bce.unb.br/bitstream/10482/4187/1/2009_ DaniellaBuchmannUngarelli.pdf. Accessed 25 April 2011)

Nieuwkoop M van, Uquillas JE (2000) Defining Ethnodevelopment in Operational Terms : Lessons from the Ecuador Indigenous and Afro-Ecuadorian Peoples Project. LCR Sustainable Development Working Papers 6, World Bank

Velloso AD (2007) Mapeando narrativas: uma análise do processo histórico espacial da comunidade do Engenho II Kalunga. Unpublished Master thesis. Department of Anthropology, Universidade de Brasilia, DF, Brasil

Vogt WP (2005) Dictionary of statistics and methodology: a nontechnical guide for the Social Sciences. SAGE, London

Volery T (2007) Ethnic entrepreneurship: a theorical framework. Handb Res Ethn Minor Entrepreneurship 1:30-41

Waldinger R, Aldrich H, Ward R (1990) Ethnic entrepreneurs: immigrant business in industrial socities. SAGE, London

Weik T (1997) The archaelogy of maroon societies in the Americas: resistance, cultural continuity, and transformation in the African diaspora. Hist Archaeol 31(2):81-92

Wickham PA (1998) Strategic entrepreneurship: a decision-making approach to new venture creation and management. Pitman Publishing, London

Willis K (2005) Theories and practices of development. Routledge, New York

Wood RE (1984) Ethnic tourism, the state, and cultural change in Southeast Asia. Annals Tour Res 11(1):353-374

Yang L, Wall G (2008) Ethnic tourism and entrepreneurship: xishuangbanna, Yunna, China. Tour Geogr 10(4):522-544

Yinger MJ (1985) Ethnicity. Annual Review of Sociology 11, pp. 151-180

Zimmerer TW, Scarborough NM (2005) Essentials to entrepreneurship and small business management. Prentice Hall Inc. New Jersey 